\title{
A REVIEW OF DEVELOPMENTS IN INTEGRATED PEST MANAGEMENT (IPM) OF BAGWORM (Lepidoptera: Psychidae) INFESTATION IN OIL PALMS IN MALAYSIA
}

\section{BRIAN J WOOD* and NORMAN KAMARUDIN**}

\begin{abstract}
Severe and unprecedented outbreaks of bagworms and nettle caterpillars occurred on oil palm plantations in the Malaya in late 1950s to early 1960s, caused by applications of organochlorine insecticides, which killed insect natural enemies more effectively than they did the pests. Outbreaks mostly declined when applications ceased, sometimes with resurgence because the pesticides also upset the co-ordination of pest and enemy life cycles. Selective pesticides were found ('integrated control'), and there was general freedom from serious outbreak until around 1990. Incidence, particularly of bagworms, then again became common, with parallel increase in pesticide use. A range of investigations have progressed over the years. During the 1960s, clean weeding had been indicated as conducive to caterpillar pest outbreak by removing shelter and floral food of the natural enemies. Field trials have shown that several beneficial plant species could extend the life of parasitoids, and where planted, bagworm numbers declined whilst natural enemy numbers relatively increased. On-going studies screened additional chemicals mostly emphasising selective potential through stomach action and specific lethality to caterpillars. Microbial pathogens were sought in the field for testing on bagworms by applying suspensions of ground up cadavers, as proven effective for nettle caterpillars. Strong attraction of male bagworms to a female pheromone was demonstrated, suggesting promise of a practical trapping technique. Predators such as Sycanus dichotomus build up in high caterpillar populations, indicating potential of rearing for mass field release to quickly reduce outbreaks. All of these methods could aid in restoring and maintaining subeconomic levels of leaf-eating caterpillars in a balanced and sustainable agroecosystem.
\end{abstract}

Keywords: bagworms (Psychidae), nettle caterpillars (Limacodidae), insect parasitoids, insect predators, mass release, entomopathogens, pheromones, selective pesticides, natural balance.

Date received: 9 August 2019; Sent for revision: 9 August 2019; Received in final form: 31 October 2019; Accepted: 6 November 2019.

\section{INTRODUCTION}

Damaging outbreaks of leaf-eating bagworms and nettle caterpillars on oil palm plantations in Malaya

\footnotetext{
Merrivale, Exton Lane, Exton, Exeter, EX3 OPP,

United Kingdom.

E-mail: brian.jwood@outlook.com

** Malaysian Palm Oil Board, 6 Persiaran Institusi, Bandar Baru Bangi, 43000 Kajang, Selangor, Malaysia.
}

(later Peninsular Malaysia) in the late 1950s and early 1960s were shown to be due to the application of organochlorine insecticides that were newly available at that time (Wood, 1971). These were disrupting the prevailing strong control by insect natural enemies, in balance with potential pests. Disruptive chemicals are broad spectrum long residual contact (BSLRC) pesticides to which a broad range of insect groups are susceptible. They have 
greater effect on mobile parasitoids and predators than on the more static pests. Ceasing application generally resulted in decline in the pest population, down to the insignificance that previously prevailed. The disruptive chemicals also tended to upset the life cycle co-ordination between pests and their enemies, so recovery could be slow, and leave a tendency to recur. Selective pesticides (lacking one of the disruptive characters) were brought in to speed the restoration in 'integrated control' (Wood and Norman, 2019).

These events focussed attention on the importance of recognising ecological factors in pest regulation. The use of selective pesticides to complement on-going 'background' natural control contributed to the developing science that became known as integrated pest management (IPM). There was a long period without major incidence until, after about 1990, when there was a gradual increase in infestation, particularly of bagworms. By today, infestation is widespread and intensive in many places. Nevertheless, other oil palm growing areas remain free of attack, indicating that the basic ecology has not changed. Pesticide treatments are applied in the affected areas, often without much appreciation of selectivity. Wood and Norman (2019) suggest that there should be a close investigation of the relationship between current regular treatments and continuing infestation.

Over the years, extensive technical investigation has been carried out, wherever bagworm presence has been prominent. This continues to build up knowledge so as to achieve greater precision in minimising threats of outbreaks and possible crop losses. Findings have covered details of bagworm biology; the natural enemy complex; the relationship of bagworm activity to environmental factors, in particular nectar producing flowers within in the ground vegetation; use of microbial pathogens; the mass trapping of bagworm moths by pheromone attractant in sticky traps and the possible mass rearing and release of a predator.

\section{BAGWORM BIOLOGY}

\section{Species}

Since the findings of the 1950s and 1960s (Wood, 1968), there has been much further investigation of the biology of the three main bagworm species attacking oil palms in South-east Asia. These are Metisa plana, Pteroma (Cremastopsyche) pendula and Mahasena corbetti. Among several other species occasionally found on the palm, only one, Dapula (Clania) tertia, has reached outbreak status and that only once, in Sumatra. These main ones are all native, widespread, and polyphagous, and have adapted to the oil palm as a complete food source since its introduction. Estimated basic bionomics are summarised in Table 1.

\section{Life Cycle}

The instars, egg numbers and life cycle lengths vary in proportion to the size of the respective caterpillars. The mean of about 2000 eggs of $M$. corbetti, found by Syed (1970) is in contrast with the 3000 indicated by Wood (1968), but the range in any population study is quite wide. Basri and Kevan (1995) mentioned that in general, the fecundity tends to be greater in individuals in captivity than in those collected from the field. Ho et al. (2010) found a somewhat faster egg to adult time in field-reared against laboratory-reared full grown females, for both $M$. plana (overall mean 74 against 83 days) and P. pendula (50 against 57). The life cycle lengths for M. plana and P. pendula from Yusof et al. (2013) are in the $30^{\circ} \mathrm{C}$ treatment in a trial on effects of varying temperature. The life cycle length gets longer at lower temperatures down to $15^{\circ} \mathrm{C}$ and shortens up to $35^{\circ} \mathrm{C}$, with no development outside this range. Reasons for variations between the studies cited (Table 1) include different trial conditions, and probably inherent differences in source populations. Importantly, the variation in any particular study tends to be narrow, so discrete generation time (DGM) once it appears in a particular outbreak, is likely to be fixed for some generations. Basri and Kevan (1995) noted that of the damage that bagworms do to leaf tissue, about $30 \%$ is for case building and $70 \%$ for feeding. Ho et al. (2010) showed that an individual M. plana consumes about three times as much leaf material as does P. pendula.

TABLE 1. BROAD ESTIMATES OF LIFE HISTORY PARAMETERS FOR THREE IMPORTANT OIL PALM BAGWORMS IN SOUTH-EAST ASIA

\begin{tabular}{lclc}
\hline & M. corbetti & M. plana & P. pendula \\
\hline Larval instars - & $11-12^{3}$ & $6-7^{1,3}$ & $4-5^{3,6}$ \\
number & & $5-7^{6}$ & \\
Eggs - number & $2000^{3}$ & $100-300^{4}$ & $65^{4}$ \\
per female & $3000^{4}$ & $100 \pm 6 \mathrm{fd}^{1}$ & \\
& & $158 \pm 10 \mathrm{lab}^{1}$ & \\
Estimates of & $117-124^{3}$ & $120^{3}$ & $70^{3}$ \\
days egg to adult & $100-120^{4}$ & $100^{4}$ & $<100^{4}$ \\
& $125-160^{2}$ & $80-90^{1}$ & \\
& & $72^{6}$ & $44^{6}$ \\
& & $77 \mathrm{fd}^{5}$ & $50 \mathrm{fd}^{5}$ \\
& $93 \mathrm{lab}^{5}$ & $57 \mathrm{lab}^{5}$ \\
\hline
\end{tabular}

Source: ${ }^{1}$ Basri and Kevan (1995) (fd - field collected; lab controlled environment room).

${ }^{2}$ Sankaran (1970) (field conditions).

${ }^{3}$ Syed (1978) (field cages).

${ }^{4}$ Wood (1968) (field conditions).

${ }^{5}$ Ho et al. (2010) (Fd - field; lab - ambient laboratory conditions). ${ }^{6}$ Yusof et al. (2013) (controlled environment room at $30^{\circ} \mathrm{C}$ ). 


\section{INSECT NATURAL ENEMIES}

\section{Species Complex}

Wood (1968) reared and illustrated several parasitoids from M. plana and P. pendula, some of which were identified. They included Dolichogenidea (Apanteles) metesae which was first described in 1967. Sankaran (1970) and Sankaran and Syed (1972) summarised the known natural enemies of bagworm at that time, based from the literature, museum collections, and their own field investigations. They showed a similar species range between Peninsula and Sabah. Parasitoids are mainly several families of Hymenoptera, with some Diptera (flies) especially from species of bigger sized individuals (Table 2). Further investigations from field collections are from Tiong (1979), Basri et al. (1995), Teh (1996), and a comprehensive account by Norman et al. (1996). The Palm Oil Research Institute of Malaysia (PORIM), later the Malaysian Palm Oil Board (MPOB) produced a useful descriptive Handbook of the main enemies of bagworms and nettle caterpillars (Norman et al., 1998), and an expert system on a Powerpoint module (Norman and Basri, 2002).

Several species from families of parasitoids are common to most collections where bagworms are active, as listed in Table 2. This suggests particular importance to those species in regulating pest populations.

\section{Levels of Parasitism}

The percentage of pest individuals that are parasitised varies greatly according to circumstances, but sometimes high parasitisation rates are found - for example, Sankaran and Syed (1972) reported levels between $18 \%-70 \%$ parasitism of M. plana by D. metesae in several samples on one occasion. There were suggestions that importation of exotic parasites might be appropriate, but the high degree of control indicated in undisturbed populations suggests that the cost and resources required to pursue the importation would not be justified. Basri et al. (1995) noted high parasitism levels (up to $26 \%$ ) on $M$. plana in a naturally declining population. Desmier de Chenon et al. (1990) dealt mainly with nettle caterpillars in most of their studies in Sumatra, however their limited records on bagworms indicated a natural enemy complex similar to that in Malaysian territories.

\section{Hyperparasitoids}

Hyperparasitoids (also termed secondary parasitoids), which are parasitoids attacking other parasitoids, are also common. The hyperparasitoids which were found associated with bagworms are Hymenoptera. Many hymenopteran families can function as either primary or secondary parasitoids. Some of the most commonly encountered are families Eulophidae, Eurytomidae, and Ceraphronidae. There is little objective evidence of the effect they may have in the control exercised by the primary parasitoids. They possibly interrupt or slow down the re-establishment of natural balance, but there is no evidence nor expectation that they have any significant on-going negative effect.

\section{Predators}

Predatory insects are free living species that capture and feed on bagworms. They become common during outbreaks and are variously mentioned in the studies cited above. Most common are the bugs Sycanus dichotomus and Cosmolestes picticeps (Hemiptera-Reduviidae), Cantheconidia furcellata (Pentatomidae), and a beetle Callimerus arcufer (Coleoptera-Cleridae). The hemipterans have a sharp proboscis to penetrate the prey insect and suck out its body fluids, with the reduviids particularly suited to feed on bagworms. The grubs of $C$. arcufer inhabit the bagworm cases and eat the contents. The predators are generalist feeders (wide host range) and will build up when an outbreak is already occurring.

TABLE 2. FREQUENTLY FOUND PARASITOIDS OF THE MAIN OIL PALM BAGWORMS FROM 1970 to $2002 *$

\begin{tabular}{llll}
\hline Bagworm & Super Family & Family & Species \\
\hline Metisa plana & Hymenoptera & Braconidae & Dolicogenidea (Apanteles) metesae, Aulosaphes psychidivorus \\
& & Ichneumonidae & Goryphus bunoh, G. inferus, Fislistina sp. \\
& Chalcididae & Brachymeria spp. \\
& Eulophidae & Tetrastichus sp., Pediobius sp. \\
Pteroma pendula & Hymenoptera & Elasmidae & Elasmus sp. \\
& & Chaconidae & D. metesae, A. psychidivorus \\
& & Eulophidae & Prachymeria spp. \\
Mahasena corbetti & Hymenoptera & Ichneumonidae & Ecthromorpha agrestoria \\
& Diptera & Tachinidae & Eozenillia equatoralis, Palexorista solennis, Thrycolida \\
& & & psychidarum, Exorista quadrimaculata
\end{tabular}

Note: *For authorities, see section on Species Complex. 


\section{GROUND VEGETATION FLOWERS AND NATURAL ENEMIES}

\section{Vegetation Removal in Relation to Outbreak}

Syed and Shah (1977) observed that the destruction of ground vegetation caused a deprivation of food and shelter for adult parasitoids, which could be causative of leaf-eating caterpillar outbreaks. Subsequently, there has been detailed investigation of the suitability of various flower species that can grow in the oil palm environment to support natural enemies.

\section{Nectar Food Source and Natural Enemy Species}

Basri et al. (1995) put field collected M. plana into cages to allow parasitoids, hyperparasitoids and the predator $C$. arcufer to emerge. They compared survival of the emerging natural enemies with and without addition of diluted honey as a food source for the adult enemies. The adult parasitoids fed with diluted honey could survive up to nine times longer than control. The authors concluded that this is evidence to support the maintenance of some flowering cover crops under the oil palms. Ho and Teh (1999) reported on the establishment of Euphorbia heterophylla (Euphorbiaceae) on a plantation scale. Various planters established a range of flowering plants on open patches within plantations (Singh, 1992). Several systematic investigations ensued to determine the support given by various plants for key parasitoids. Basri et al. (1999) assessed the longevity of seven species on the flowers of nine plants that could be cultivated among palms, in comparison with diluted honey. The test insects were field collected and subject to laboratory feeding trials. The survival of $D$. metesae varied greatly between the test plants. Highest was Cassia cobanensis (Fabaceae), which together with Asystasia gangetica (previously misidentified as $A$. intrusa) (Acanthaceae) and Crotalaria usaramoensis (Fabaceae), were in the same order as diluted honey. The other plants were similar as 'no food provided', including E. heterophylla, Euphorbia hirta, Hedyotis verticillata, Hedyotis corymbosa (Rubiaceae), Cleome rutidisperma (Capparaceae), and Ageretum conyzoides (Asteraceae). Among the other insects tested, Brachymeria carinata, Eupelmus catoxanthae and Pediobius imbreus had the greatest longevity, whilst $C$. cobanensis, C. usaramoensis, and E. heterophylla provided some support to the parasitoids, but with a difference of ranking. A. gangetica was favoured by $D$. metesae but was less useful to larger ichneumonid species.

\section{Comparison of Various Plants}

Basri et al. (2001) field tested some beneficial plants for their attraction to several key parasitoids. Three of the most promising plants in this study were established in polybags and then placed in open patches within 0.4 ha oil palm plots. The parasitoid populations were assessed by systematic field observations. A. gangetica was omitted in view of its weed status, but similar observations were made in plots of that plant in estate conditions outside the trial area. Over the four-year (1996-99) study period, 370 parasitoids were collected from $C$. cobanensis, but only eight from E. heterophylla, five from C. usaramoensis, and one from $A$. gangetica. The commonest parasitoids were Brachymeria spp. with D. metesae, Eurytoma sp. and Goryphus bunoh being less common, while Tetrastichus spp., E. catoxanthae and a ceraphronid were rarely collected. In parallel, bagworms were sampled from palms in the field to allow for parasitoid emergence. Among 666 individuals from the larval stages, D. metesae emerged most commonly (with 268 individuals), with E. catoxanthae (134), Eurytoma sp. (78), Pediobus anomalus (78), Tetrastichus sp. (66), P. imbreus (35), B. carinata (6), and P. varius (1). From the pupal stages, Tetrastichus sp. had emerged the most frequently (336 individuals of 494), together with Brachymeria carinata (49), P. anomalus (43), E. catoxanthae (27), P. imbreus (16), D. metesae (7) and G. bunoh (6). The predatory beetle, $C$. arcufer was also commonly found, with 21 from larval and 19 from pupal stages. Parasitism levels were higher near to the flowers.

Ho et al. (2003) reviewed developments in the topic in more detail. Over an 18-week trial period, they evaluated C. cobanensis and E.heterohylla, plus Antigonon leptopus (Polygonaceae), Crotallariazanzibarensis, Turnera subulata (Passifloraceae) and A. gangetica, and a control of mixed grasses, each on a $450 \mathrm{~m}$ strip alongside an 8-year old oil palm planting with 'moderate' incidence of M. plana. This indicated that parasitism was highest near to C. cobanensis and E. heterophylla, in the order of $10 \%$ to $60 \%$. It was lower with the others, and least near to A. gangetica. C. arcufer was about evenly distributed irrespective of the plants. In a trial, D. metesae adults placed in a field cage with insectary reared bagworms put on an oil palm seedling, survived for an average of 1.32 days. In treatments with diluted honey, its survival was 4.71 days, and with nectariferous plants in polybags within a cage, it was 5.18 days with $E$. heterophylla and 4.75 with C. cobanensis.

During the time around the year 2000, it became standard recommendation to plant $C$. cobanensis, E. heterophylla, A. leptopus and or $T$. subulata in open spaces in plantations (Siti Ramlah et al., 2005), although by the time of a 2005 survey, only $33 \%$ of estates had taken it up (Norman and Basri, 2007). Nor Sarashimatun et al. (2011) found that parasitoids were caught more in sweep nets above Turnera ulmifolia compared to T. subulata, and therefore the former should be preferred. Several herbaceous plants captured no parasitoids. Others were checked by sweep netting, by visual recording, and by parasitoid emergence, and the 
overall recommendation to plant C. cobanensis was confirmed. Yusdayati et al. (2014) in similar studies, suggested that Turnera spp. can be better recommended because flowering is continuous, whilst $C$. cobanensis flowers seasonally and may require replanting if the growth is retarded during the dry periods.

Norman and Othman (2016) assessed the parasitoid occurrence on C. cobanensis, in an oil palm planting with $P$. pendula incidence. Data was taken quarterly from 2008 to 2010, by sweep netting and sticky trap catches in the C. cobanensis planting, and similar captures in the palm rows. Within the $C$. cobanensis planting, a similar range of parasitoids species was found as in the foregoing studies, but the proportions seemed somewhat different, in particular not many $D$. metesae and a preponderance of Brachymeria spp. Two predators, S. dichotomus and $C$. picticeps were more common. In the oil palm block with C. cobanensis, captures were quite small, and included some $C$. arcufer. Numbers seemed similarly small in the block without $C$. cobanensis alongside.

\section{Natural Enemies, Pesticides and Pest Status}

In some of the longer-term trials cited above, it is apparent that no pesticides were used, but the status of the bagworm population is not clarified. Even so, it can be assumed that if there had been any upsurge in infestation, it would have been mentioned. Reductions in M. plana numbers were attributed to parasitism supported by the flowers. This is as would be expected with no chemicals applied. Parasitoid populations need food to thrive, no doubt, but they also need the insect hosts to complete their life cycle. As they build up, bagworm host number will be reduced, and consequently so will those of their enemies, with expected change in ratios of natural enemy species. Natural balance implies rare pests with rare natural enemies (DeBach, 1964). Where it was recorded in those trials, parasitoid emergence also reduced in tandem with bagworm population decline. Also, the ratios between natural enemy species and the host bagworm changed. An important implication is that presence and proportions of parasitoid species are not necessarily exactly indicative of their relative importance in reducing the bagworm infestation, nor in maintaining very low numbers of the pest host.

\section{INVESTIGATIONS FOR NEWER OR ALTERNATIVE TREATMENTS}

\section{Chemicals}

Frequently used. Four pesticide treatments have become 'standard' in Malaysian oil palms over the decades, namely systemic organophosphates (by trunk injection, TI), materials derived from Bacillus thuringiensis, trichlorfon, and synthetic pyrethroids (Wood and Norman, 2019).

Other synthetic chemicals. Various such pesticides have been tested or used in control efforts, on smaller or less regular scale. Potential selectivity has been a common but not invariable criterion. Wood (1976) listed several organophosphates, carbamates, and the chlorinated hydrocarbon, endosulphan. Many gave good kill, but most are no longer available. Some had disruptive characters, but were used for a time without repercussion e.g. phosmet (Ho, 1988; Chung and Narendran, 1996; Chung, 1998). This illustrates the chance element in selectivity. Efforts to increase the range of 'safe' spray chemicals continued during the 1990s but were becoming less pressing with the development of TI. Sumantri et al. (2011) investigated several insecticides against $M$. plana on young palms in Sumatra. Of those with enough promise to justify large scale testing for selectivity were acephate, a systemic organophosphate, with reputed fast fading contact residue, cartap hydrochloride and thiosultap (=dimehypo) (both nereistoxin systemic antifeedants), and thiodicarb (carbamate, systemic and predominantly stomach acting). Thiosultap was found to give a good kill of M. plana in trials (Sunindyo et al., 2012).

A more recent addition to the range of possible chemicals is chlorantraniliprole, an antifeedant of primarily stomach action, with little effect against most groups of natural enemies (Tomlin, 2009). In trials, it has given good kill of M. plana in comparison with the 'standard' treatments, trichlorfon and cypermethrin (Ooi et al., 2012).

Insect growth regulators (IGR). Insect growth regulators are likely to be selective in the present context. This is because the leaf-eaters are in the larval stage and still have to develop, whilst most natural enemies that have contact with the chemicals are mature. Further, they are mainly stomach acting. Those tested in oil palms include the chitin synthesis inhibitors chlorfluazuron, diflubenzuron, teflubenzuron and trflumuron. Trials suggest that they can effectively kill bagworms (Chung, 1988; Hoong and Ho, 1992).

\section{Root Infusion as an Application Method for Systemic Chemicals}

Systemic insecticides like those used in TI can be absorbed into the crown of coconut and oil palms by a severed root end put into a bag of the concentrate (Ginting and Desmier de Chenon, 1987; Mariau and Genty, 1992). This has not been taken up on estate scale as the logistics are difficult and associating a particular root with its parent palm is not exact. 


\section{Pathogens}

Fungal and viral diseases can spread through leaf-eating oil palm caterpillar populations, and they may be manipulated in applied control. Early findings on the occurrence of virus from nettle caterpillars indicated that viral infection sometimes increased spontaneously to terminate the infestation, such as Darna trima in Peninsula (Wood, 1968), Sibine fusca in Colombia (Genty and Mariau, 1975) and Setothosea asigna in Sumatra (Desmier de Chenon et al., 1988). Field collections of infected caterpillars, dried and applied in suspension to affected palms, can infect the feeding caterpillars and reduce infestation (e.g. Syed et al., 1974; Tiong and Monroe, 1977).

Pathogens of bagworms were only noted later. Tiong (1979) in Sarawak collected M. corbetti from an outbreak area with a high proportion of dead individuals and kept them dry in cages for observation. Apart from emergence of several parasitoids and predators, he found that the caterpillars were evidently infected by a fungus, Paecilomyces fumosoroseus and by a non-occluded RNA virus. Possibilities for application in the field for control were not pursued due to erratic results, but Teh (1996) reported some field-scale use of the virus. Syed and Saleh (1993), noted that a virus in Sumatra, reported as 'introduced from Malaysia', was lethal to $M$. corbetti, and they observed that there were no pathogens of $M$. plana known at that time. Teh (1996) mentioned recording the fungus Paecilomyces lilacinus from M. plana.

Siti Ramlah and Jalani (1993) reviewed the incidence and possible use of virus on nettle caterpillars, and the possibility of infecting the bagworms M. plana and P. pendula. The possibility of adapting a Baculovirus of these species was investigated by Siti Ramlah et al. (1996). They collected $62000 \mathrm{M}$. plana at various stages in the field, with 1000 other leaf eaters. Virus was detected but found no promise of practical use at that stage. However, Siti Ramlah et al. (1994) reared a range of fungal pathogens, from field collected newly dying M. plana, of which Beauveria bassiana appeared most likely to be usable, with some promise for Paecilomyces farinosus. B. bassiana was shown to give high mortality in laboratory tests (Ramle et al., 1993). In subsequent field tests, water-based applications sustained detrimental effects from drying out and ultra-violet radiation. The latter could be overcome by sunscreen formulation with six oils tested, including soyabean and paraffin (Ramle et al., 2004), in order to do field testing. P. pendula was also tested with three field collected strains of Beauveria brongniartii and one B. bassiana (Nor Shalina et al., 2010). All gave lethal infection, whilst work was still required on maximising spore concentration for any practical applications.
Pathogen application offers promise of highly selective control, but at present there is no commercial product for use against leaf-eating pests, except the Bacillus thuringiensis toxins. Field tests to date remain largely from direct field application of suspensions of ground up diseased cadavers. It seems worthwhile to pursue this option although with the sporadic need, it could be problematic to have infective material ready at the time of outbreak. Multiplication in alternative hosts easily bred in the laboratory offers possibilities, such as Spodoptera litura for Baculovirus (Siti Ramlah et al., 1996). The narrow spectrum is key to selectivity, whilst a pathogen lethal to other leaf eaters in other crops might offer sales potential to justify production facilities.

\section{Pheromones}

Adult bagworm females remain within their bags, from where the hatching young larvae emerge. At the receptive stage, bagworm males fly to them for mating. There is clearly a pheromone attraction, as shown by placing receptive females on sticky traps that allow recording of male visits (Rhainds, 2000; Norman and Othman, 2006). Norman et al. (2010) assessed the effect of setting sticky traps with virgin females. They found evidence of a drop in subsequent bagworm population due to reduced mating success, with accompanying benefit on palm production. Mohd Najib et al. (2017) in field scale trapping showed a reduction in numbers of $M$. plana. These results appear to indicate the prospect of a practical technique for control in infested plantings. The chemical structure of the specific pheromone has yet to be isolated, but the possibility of synthesising the correct compound merits further investigation.

\section{Mass Release of Natural Enemies}

Predator suitability. Parasitoids evidently are the enemies that could maintain very low populations of the pest, but in an outbreak situation, there is usually a heavy build up of generalist predators which could reduce the outbreak population naturally. Their feeding will fast reduce numbers of the living pests but may take some time to get going. The specialist parasitoids will tend to become scarce as the host (bagworm) numbers decline, but generalist predators are likely to increase in proportion as they continue to find prey on other vegetations as well. Thus, there is some possibility of reducing high populations, providing there are no further disruptive applications, by speeding the build up of predators through rearing and mass release into a developing infestation. Similarly, satisfactory refuge for these predators should be made available before any release is to be made. 
Rearing practicalities. S. dichotomus was an early suggestion as a candidate for mass rearing (Wood, 1976; Desmier de Chenon et al., 1990). More recently, Zulkefli et al. (2004) investigated the potential in the laboratory, with easily reared host insects caterpillars of the rice moth, Corcyra cephalonica, and a vegetable pest, Plutella xylostella. Their findings on the length of the reproductive cycle and increase potential are given in Table 3. This indicates in broad terms, a potential increase of about 100-fold every 200 days. In other words, a slow early build up in the field from 'normal' base, but a fairly fast laboratory production. and biology of bagworms and other leaf-eating caterpillars, adding to the wealth of scientific knowledge. In practice, their different characteristics in relation to their pest hosts can increase precision of applied control. Flowers producing significant nectar, growing in ground vegetation, undoubtedly aid the maintenance and recovery of parasitoid populations. Nonetheless, it is unlikely that they will fully counteract infestation induced by pesticide disruption. Since a big proportion of bagworm infestation starts in young palms, evidently the earliest possible establishment of cover after replanting is important. In general, this should be a feature of best

TABLE 3. LIFE CYCLE LENGTH AND GENERATIONAL INCREASE POTENTIAL OF Sycanus dichotomus IN LABORATORY CONDITIONS*

\begin{tabular}{lccccc}
\hline \multicolumn{2}{c}{ Range in days } & & \multicolumn{2}{c}{ Average } & \% Success of hatching \\
\cline { 1 - 2 } Egg to adult & Adult life & & Egg clusters/female & Eggs/cluster & \\
\hline $120-130$ & $60-85$ & 3 & $15-119$ & 50 \\
\hline
\end{tabular}

Source: *Zulkefli et al. (2004).

In further studies, Siti Nurulhidayah et al. (2011) compared the rice moth host with the mealworm, Tenebrio molitor. There were some differences in life span and ultimate adult weight, favouring the moth (98 days egg to adult) and mixed diet (95 days), against mealworm only (116 days). Siti Nurulhidayah and Norman (2016) found that the early nymphal stages of the predator could not easily penetrate their proboscis into the mealworm cuticle. They suggested that such factors may lead to differences in prey susceptibility in the field, notwithstanding the term 'generalised predators'. Laboratory tests with M. plana as prey (Siti Nurulhidayah et al., 2017) showed that in 48 hr, the average consumption by adult females was 12.6 bagworms (with 7.6 for $5^{\text {th }}$ nymphal stages, and 10.4 for males). The consumption per unit time was greater in the first hours of exposure, suggesting quick satiation when prey is abundant.

\section{CONCLUSION}

The basic ecology of pest incidence in oil palms is widely recognised and accepted, and the work to reinforce that is considerable. It is important that this continues to be the base for both development and operational practices. Most major plantation groups have field research operations, or, more often these days, extension units. The needs and opportunities for field experimentation and knowledgeable investigation are considerable.

The wide range of research topics gives increasingly sound background in the ecology agronomy anyway, and it is key to Oryctes control. That alone would help avoid temptation to spray broad spectrum long residue contacts.

Alternative applied control possibilities continue to offer security for future IPM technique, as they continue to receive research attention. Pathogens offer perfect selectivity, but the cost of on-going production, with only sporadic need, would be an obstacle. If there are susceptible pests of other crops in the area that regularly occur, some commercial exploitation might support production. Similar considerations apply to rearing and mass release of predators, and also to pheromone production.

Among synthetic chemicals themselves, newer possibilities with characters with strong selective potential merit further exploration. In particular, chlorantraniliprole, a stomach poison, which shows useful attributes (Wood and Norman, 2019) and which is safer to the environment and user.

Most prospects and principles apply equally to nettle caterpillars, and to other leaf-eating pests in different regions. There is no evidence that it is other than a matter of chance which group and species first appears at any particular time and locality. Once one pest species has built up, that disturbance continues at some level, making it the species most likely to recur in that broad location if conditions conducive to pest build up occur, for at least several generations.

Overall, there is enough knowledge to apply low pesticide input methods to maintain satisfactory control of oil palm bagworms and other leaf eating pests, whilst on-going research input will ensure improving sustainability. 


\section{ACKNOWLEDGEMENT}

The authors thank the Director-General of MPOB for permission to publish this article. They also thank Nur Robaatul Adhawiyah for her help in searching various articles for this review.

\section{REFERENCES}

Basri, M W and Kevan, P G (1995). Life history and feeding behaviour of the oil palm bagworm, Metisa plana Walker (Lepidoptera: Psychidae). Elaeis, 7(1): 18-35.

Basri, M W; Norman, K and Hamdan, A B (1995). Natural enemies of the bagworm Metisa plana (Lepidoptera: Psychidae) and their impact on host population regulation. Crop Protection, 14(8): 637645.

Basri, M W; Norman, K and Othman, A (2001). Field impact of beneficial plants on the parasitism levels of the bagworm, Metisa plana (Lepidoptera: Psychidae). Proc. of the 2001 PIPOC International Palm Oil Congress: Cutting-edge Technologies for Sustained Competitiveness (Unedited). 20-22 August 2001. Kuala Lumpur. 13 pp.

Basri, M W; Siburat, S; Ravigadevi, S and Othman, A (1999). Beneficial plants for the natural enemies of the bagworm in oil palm plantations. Proc. of the 1999 PORIM International Palm Oil Congress Emerging Technologies and Opportunities in the Next Millennium (Ariffin, D; Chan, K W and Sharifah, S R $S$ A eds.). PORIM, Bangi. p. 441-455.

Chung, G F (1988). Spraying and trunk injection of oil palm for pest control. Proc. of the National Palm Oil/Oil Palm Conference - Current Developments. 1115 October 1988. 44 pp.

Chung, G F (1998). Strategies and methods for the management of leaf-eating caterpillars of oil palm. The Planter, 74(871): 531-558.

Chung, G F and Narendran, R (1996). Insecticides screening for bagworm control. Proc. of the 1996 PORIM International Palm Oil Congress: Competitiveness for the $21^{\text {st }}$ Century. PORIM, Bangi. p. 484-491.

Debach, P (1964). The scope of biological control. Biological Control of Insect Pests and Weeds (Debach, P ed.). Reinhold Publishing Company, New York. p. 3-20.

Desmier de Chenon, R; Mariau, D; Monsarrat, P; Fediere, G and Sipayung, A (1988). Research into entomopathogenic agents of viral origin in leafeating Lepidoptera of the oil palm and coconut. Proc. of the 1987 International Oil Palm/Palm Oil Conference - Agriculture (Halim, A H; Chew, P S; Wood, B J and Pushparajah, E eds.). PORIM, Bangi. p. 471-479.

Desmier de Chenon, R; Sipayung, A and Sudharto, P S (1990). The importance of natural enemies on leaf-eating caterpillars in oil palm plantations in Sumatra, Indonesia - uses and possibilities. Proc. of the 1989 International Palm Oil Development Conference - Agriculture (Jalani, B S; Zin, Z Z; Paranjothy, K; Ariffin Darus; Rajanaidu, N; Cheah, S C; Mohd Basri Wahid; Henson, I E and Mohd Tayeb, D eds.). PORIM, Bangi. p. 245-262.

Genty, P and Mariau, D (1975). Utilisation d'un germe entomopathogene dans la lutte contre Sibine fusca (Limacodidae). Oleagineux, 30: 349-354.

Ginting, C U and Desmier de Chenon, R (1987). Application of the systemic insecticide root absorption technique for the long term protection of coconut palms and other commercial crops. Oleagineux, 42(2): 71-73.

Ho, C T (1988). Mechanized mistblowers for treatment of oil palm leaf pests. Proc. of the National Palm Oil/Oil Palm Conference - Current Developments. 11-15 October 1988. 17 pp.

Ho, C T and Teh, C L (1999). Integrated pest management in plantation crops in Malaysia. Challenges and realities. Proc. of the 1997 International Planters Conference - Plantation Management for the 21 Century (Pushparajah, E ed.). Vol. 1. Incorporated Society of Planters, Kuala Lumpur. p. 125-149.

Ho, C T; Yusof, I and Khoo, K C (2010). Comparative life histories, demographic statistics and damage potential of the bagworms Pteroma pendula and Metisa plana in oil palm. Jurnal Sains dan Matematik, 2(2): 39-53.

Ho, C T; Khoo, K C; Yusof, I and Dzolkifli, O (2003). Comparative studies on the use of beneficial plants for natural suppression of bagworm infestation in oil palm. Proc. of the 2003 PIPOC International Palm Oil Congress: Palm Oil, The Power-house for the Global Oil \& Fats Economy: Agriculture (Unedited). MPOB, Bangi. p. 372-424.

Hoong, H W and Ho, C K Y (1992). Major pests of oil palm and their occurrence in Sabah. The Planter, 68(793): 193-210.

Mariau, D and Genty, P H (1992). Oil palm and coconut pest control by root absorption. Oleagineux, 47(4): 194-196. 
Mohd Najib, A; Norman, K; Nurulhidayah, A S; Othman, A; Mazmira, M; Ramle, M and Kushairi, A (2017). Efficacy of pheromone trapping and aerial spraying of Bacillus thuringiensis (Bt) for controlling Metisa plana Walker (Lepidoptera: Psychidae) in Yong Peng, Johor, Malaysia. J. Oil Palm Res. Vol. 29(1): 55-65.

Norman, K and Basri, M W (2002). Parator V1.0 - A diagnostic tool for the identification of parasitoids and predators for bagworms and nettle caterpillars in oil palm. MPOB Information Series No. 134: 2 pp.

Norman, K and Basri, M W (2007). Status of common oil palm insect pests in relation to technology adoption. The Planter, 83(975): 371-385.

Norman, K; Basri, M W and Zulkefli, M (1998). Handbook of Common Parasitoids and Predators Associated with Bagworms and Nettle Caterpillars in Oil Palm. PORIM, Bangi. 29 pp.

Norman, K and Othman, A (2006). Potentials of using the pheromone trap for monitoring and controlling the bagworm, Metisa plana Wlk (Lepidoptera: Psychidae) in a smallholder plantation. J. Asia Pacific Entomology, 9(3): 281-285.

Norman, K and Othman, A (2016). Diversity and activity of insect natural enemies of the bagworm (Lepidoptera: Psychidae) within an oil palm plantation in Perak, Malaysia. J. Oil Palm Res. Vol. 28(3): 296-307.

Norman, K; Walker, A K; Mohd Basri, W; Lasalle, J and Polaszek, A (1996). Hymenopterous parasitoids of the bagworm, Metisa plana and Mahasena corbetti on oil palm in Peninsular Malaysia (1996). Bulletin of Entomological Research, 86: 423-439.

Norman, K; Siti Nurulhidayah, A; Othman, A and Basri, M W (2010). Pheromone mass trapping of bagworm moths, Metisa plana Walker (Lepidoptera: Psychidae), for its control in mature oil palms in Perak, Malaysia. J. Pacific Entomology, 13: 101-106.

Nor Sarashimatun, S; Teh, C L and Tey, C C (2011). Evaluation of beneficial plants as hosts for natural enemies of oil palm bagworms. Proc. of the PIPOC 2011 International Palm Oil Congress: Palm Oil Fortifying and Energizing the World (Agriculture, Biotechnology and Sustainability Conference). MPOB, Bangi. p. 36-40.

Nor Shalina, A T; Siti Ramlah, A A; Shamsilawani, A B and Nor Erlina, K (2010). Effect of Beauvaria brongniartii and B. bassiana on oil palm bagworm, Pteroma pendula (Joannis). J. Oil Palm Res. Vol. 22: 729-735.
Ooi, K E; Zulkarnain, I; Chua, C K and Lee, K L (2012). Chlorantraniliprole: A novel insecticide for bagworm (Metisa plana) and nettle caterpillar (Setora nitens) management in oil palm plantation. Proc. of the $4^{\text {th }}$ IOPRI-MPOB International Seminar: Existing and Emerging Pests and Diseases of Oil Palm, Advances in Research and Management. Bandung, Indonesia, 13-14 December 2012. p. 126-136.

Ramle, M; Basri, M W; Siti Ramlah, A A and Norman, K (2004). The effects of oils on germination of Beauvaria bassiana (Balsamo) Vuillemin and its infection against the oil palm bagworm, Metisa plana (Walker). J. Oil Palm Res. Vol. 16(2): 78-87.

Ramle, M; Siti Ramlah, A A; Basri, M W and Sharifah Azura, S I (1993). In-vitro studies of Beauveria bassiana (Bals.) Vuill. and its infection on bagworm, Metisa plana Wlk. Proc. of the 1993 PORIM International Palm Oil Congress: Update and Vision - Agriculture. p. 669673.

Rhainds, M (2000). A review of recent sampling and ecological studies on bagworms (Lepidoptera: Psychidae) in commercial plantations of oil palm. The Planter, 76(886): 9-14.

Sankaran, T (1970). The oil palm bagworms of Sabah and the possibilities of their biological control. PANS, 16: 43-55.

Sankaran, T and Syed, R A (1972). The natural enemies of bagworms on oil palms in Sabah, East Malaysia. Pacific Insects, 14: 57-71.

Singh, G (1992). Management of oil palm pests and diseases in Malaysia in 2000. Pest Management and the Environment in 2000 (Aziz, A; Kardar, S A and Barlow, H S eds.). p. 195-212.

Siti Nurulhidayah, A and Norman, K (2016). Growth and longevity of the insect predator, Sycanus dichotomus Stal. (Hemiptera: Reduviidae) fed on live insect larvae. J. Oil Palm Res. Vol. 28(4): 471-478.

Siti Nurulhidayah, A; Norman, K and Zulkefli, M (2011). Mixed preys as food sources for mass rearing the bagworm predator, Sycanus dichotomus. $M P O B$ Information Series No. 486: 2 pp.

Siti Nurulhidayah, A; Othman, A and Norman, K (2017). Assessment of voracity and predatory efficiency of Sycanus dichotomus (Hemiptera: Reduviidae) to larvae of bagworm Metisa plana (Lepidoptera: Psychidae) in cage studies. Proc. of the PIPOC 2017 International Palm Oil Congress: Treasure the Past Charting the Future (Agriculture, Biotechnology $\mathcal{E}$ Sustainability Conference). MPOB, Bangi. p. 100103. 
Siti Ramlah, A A and Jalani, B S (1993). Viral control of oil palm insect pests. PORIM Bulletin No. 26: 1826.

Siti Ramlah, A A; Basri, M W and Ramle, M (1996). Isolation and amplification of Baculovirus as a biocontrol agent for bagworms and nettle caterpillars of oil palm. Elaeis, 8(1): 1-9.

Siti Ramlah, A A; Ramle, M and Basri, M W (1994). The characteristics of indigenous entomopathogenic fungi isolated from insect pests of oil palm. Elaeis, 6(1): 6-13.

Siti Ramlah, A A; Mohd Basri M W; Mohd Najib, A and Mohamed Mazmira, M M (2005). Integrated pest management: Terakil-1, Cassia cobanensis and beneficial insects for controlling of bagworms infestation in Malaysia. Proc. of the PIPOC 2005 International Palm Oil Congress: Technologies Breakthroughs and Commercialization the Way Forward. MPOB, Bangi. p. 660-690.

Sumantri, A; Cahyasiwi, L; Wood, B J and Saleh, A (2011). Development of selective measures and strategies for nettle caterpillar and bagworm control on oil palms in Sumatra. Proc. of the PIPOC 2011 International Palm Oil Congress: Palm Oil: Fortifying and Energising the World (Agriculture, Biotechnology and Sustainability Conference). MPOB, Bangi. p. 612624.

Sunindyo, D; Simanjuntak, D and Susanto, A (2012). The effectiveness of Marathon 500SL (active ingredient:dimehypo $500 \mathrm{~g} / \mathrm{L}$ ) against bagworm Metisa plana at immature of oil palm in Afdeling III, Block 08 Q, Dolok Sinumbah Estate of PT Nusantara Plantation IV, North Sumatra Indonesia. Proc. of the $4^{\text {th }}$ IOPRI-MPOB International Seminar: Existing and Emerging Pests and Diseases of Oil Palm, Advances in Research and Management. Bandung, Indonesia, 1314 December 2012. p. 98-105.

Syed, R A (1970). Biological control possibilities of some insect and weed pests in Sabah. Proc. of the Crop Protection Conference. Kuala Lumpur. 15-17 November. p. 124-132.

Syed R A, (1978). Bionomics of the three important species of bagworms on oil palm. Malaysian J. Agriculture, 51: 392-398.

Syed, R A and Saleh, A (1993). Management of insect pests of oil palm in PT PP London Sumatra Indonesia plantations in Sumatera, Indonesia. Proc. of the 1991 PORIM International Palm Oil Conference: Progress, Prospects and Challenges towards the $21^{\text {st }}$ Century. Module I - Agriculture (Yusof Basiron; Jalani Sukaimi; Chang, K C; Cheah, S C; Henson, I
E; Norman Kamarudin; Paranjothy, K; Rajanaidu, N; Mohd Tayeb Dolmat and Ariffin Darus eds.). PORIM, Bangi. p. 451-457.

Syed, R A and Shah, S (1977). Some important aspects of insect pest management in oil palm estates in Sabah, Malaysia. International Developments in Oil Palm (Earp, D A and Newall, W eds.). Incorporated Society of Planters, Kuala Lumpur. p. 577-590.

Syed, R A; Shah, S and Sankaran, T (1974). Investigations on biological control of oil palm bagworms in Sabah. Progress Report 1969-1973, Commonwealth Institute of Biological Control, Sabah Sub-station, Tuaran. $67 \mathrm{pp}$.

Teh, C L (1996). Integrated pest management of leafeating caterpillars of oil palms in Sabah. The Planter, 72(844): 395-405.

Tiong, R H C (1979). Some predators and parasites of Mahasena corbetti (Tams) and Thosea asigna (Moore) in Sarawak. The Planter, 55(639): 279-289.

Tiong, R H C and Monroe, D D (1977). Microbial control of an outbreak of Darna trima (Moore) on oil palm (Elaeis guineensis Jacq.) in Sarawak. International Developments in Oil Palm (Earp, D A and Newall, W eds.). Incorporated Society of Planters, Kuala Lumpur. p. 624-640.

Tomlin, C D S (2009). The Pesticide Manual. 15 Edition. British Crop Protection Council, Alton Hampshire. 1457 pp.

Wood, B J (1968). Pest of Oil Palms in Malaysia and their Control. Incorporated Society of Planters. 204 pp.

Wood, B J (1971). Chapter 19: Development of integrated control programmes for pests of tropical perennial crops in Malaysia. Biological Control (Huffaker, C B eds.). Plenum Press, New York. p. i-xix, 1-511.

Wood, B J (1976). Insect pests in South East Asia. Oil Palm Research (Corley, R H V; Hardon, J J and Wood, B J eds.). Elsevier, Amsterdam. p. 347-367.

Wood, B J and Norman, K (2019). Bagworm (Lepidoptera: Psychidae) infestation in the centennial of the Malaysian oil palm industry - A review of causes and control. J. Oil Palm Res. Vol. 31 (3): 364-380.

Yusdayati, R; Che Salmah, M R; Abu Hassan, A and Noor Hisham, H (2014). Diversity and distribution of natural enemies (predators and parasitoids) of bagworms (Lepidoptera: Psychidae) on selected host plants in an oil palm plantation. The Planter, 90(1055): 91-101. 
Yusof, I; Ho, C T and Khoo, K C (2013). Effects of temperature on the development and survival of the bagworms Pteroma pendula and Metisa plana (Lepidoptera: Psychidae). J. Oil Palm Res. Vol. 25: 1-8.
Zulkefli, M; Norman, K and Basri, M W (2004). Life cycle of Sycanus dichotomus (Hemiptera: Pentatomidae) - A common predator of bagworm in oil palm. J. Oil Palm Res. Vol. 16(2): 50-56.

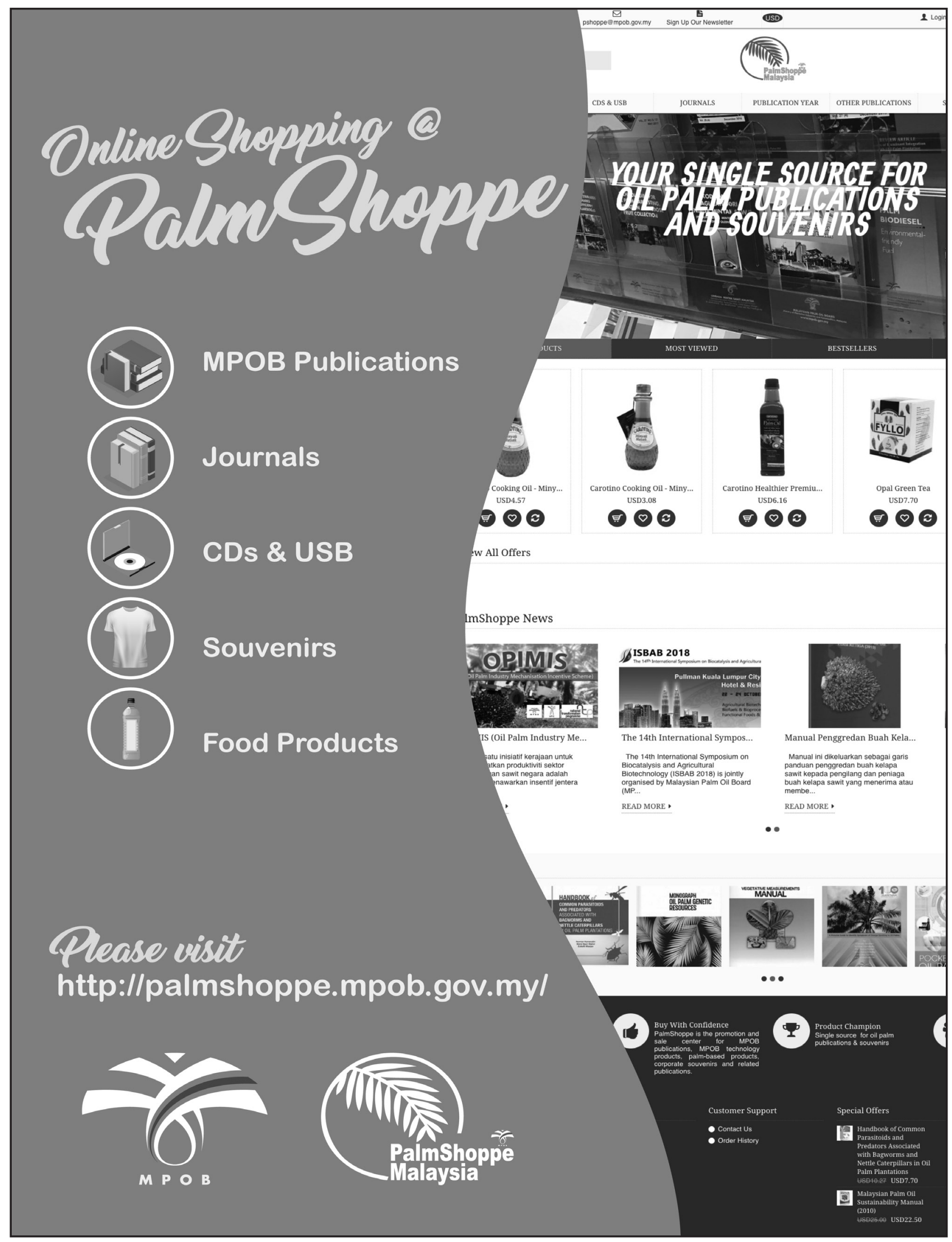

